\title{
A Roadmap for Participatory Chestnut Breeding for Nut Production in the Eastern United States
}

\author{
Ronald S. Revord ${ }^{1 *}$, Gregory Miller ${ }^{2}$, Nicholas A. Meier ${ }^{1}$, John Bryan Webber', \\ Jeanne Romero-Severson ${ }^{3}$, Michael A. Gold ${ }^{1}$ and Sarah T. Lovell ${ }^{1}$ \\ 'School of Natural Resources, Center for Agroforestry, University of Missouri, Columbia, MO, United States, ${ }^{2} E m p i r e$ \\ Chestnut Company, Carrollton, OH, United States, ${ }^{3}$ Department of Biological Sciences, 327 Galvin Life Sciences, \\ University of Notre Dame, Notre Dame, IN, United States
}

OPEN ACCESS

Edited by:

Nicolas Rispail,

Spanish National Research

Council (CSIC), Spain

Reviewed by:

Ernesto Igartua,

Spanish National Research

Council (CSIC), Spain

Tom Gradziel,

University of California,

Davis, United States

*Correspondence:

Ronald S. Revord

r.revord@missouri.edu

Specialty section:

This article was submitted to

Plant Breeding,

a section of the journal

Frontiers in Plant Science

Received: 02 July 2021

Accepted: 29 November 2021

Published: 03 January 2022

Citation:

Revord RS, Miller G, Meier NA, Webber JB, Romero-Severson J, Gold MA and Lovell ST (2022) A Roadmap for Participatory Chestnut

Breeding for Nut Production in the

Eastern United States.

Front. Plant Sci. 12:735597.

doi: 10.3389/fpls.2021.735597
Chestnut cultivation for nut production is increasing in the eastern half of the United States. Chinese chestnuts (Castanea mollissima Blume), or Chinese hybrids with European (C. sativa Mill.) and Japanese chestnuts (C. crenata Sieb. \& Zucc.), are cultivated due to their high kernel quality, climatic adaptation, and disease resistance. Several hundred thousand pounds of high-quality fresh nuts are taken to market every fall, and several hundred additional orchards are entering bearing years. Grower-led on-farm improvement has largely facilitated this growth. A lack of significant investments in chestnut breeding in the region, paired with issues of graft incompatibility, has led many growers to cultivate seedlings of cultivars rather than grafted cultivars. After decades of evaluation, selection, and sharing of plant materials, growers have reached a threshold of improvement where commercial seedling orchards can be reliably established by planting offspring from elite selected parents. Growers recognize that if cooperation persists and university expertise and resources are enlisted, improvement can continue and accelerate. To this end, the University of Missouri Center for Agroforestry (UMCA) and chestnut growers throughout the eastern United States are partnering to formalize a participatory breeding program - the Chestnut Improvement Network. This partnership entails the UMCA providing an organizational structure and leadership to coordinate on-farm improvement, implement strategic crossing schemes, and integrate genetic tools. Chestnut growers offer structural capacity by cultivating seedling production orchards that provide financial support for the grower but also house segregating populations with improved individuals, in situ repositories, and selection trials, creating great value for the industry.

Keywords: chestnut, Castanea, tree breeding, participatory, repository, conservation

\section{INTRODUCTION}

Chestnut (Castanea spp.) is currently a minor crop in the United States, and investment in chestnut breeding has been minimal to date (Anagnostakis, 2012). However, commercial production of Chinese chestnuts and complex hybrids is expanding in the eastern states, with over 300 bearing age orchards and an additional 300 newly established (1-5-year-old) orchards (USDA, 2018). 
Given an increasing chestnut grower base across diverse environments (Texas north to Nebraska and every state to the East), formalizing an organized breeding network would support and bolster this growth. Growers tend to be deeply passionate stewards and proponents of the crop, with a great desire to assist in and benefit from genetic improvement efforts. At present, most improvement efforts have been undertaken by growers, many of whom are members of the Northern Nut Growers Association (NNGA) and/or Chestnut Growers of America (CGA). However, improvement activities often occur independently and would benefit from greater organization and coordination. Researchers at the University of Missouri Center for Agroforestry (UMCA), who have worked on chestnut improvement for over two decades, are currently establishing a partnership with growers in the form of a participatory breeding network. This network aims to enhance and coordinate grower efforts by providing institutional support, including creating an online database of on-farm germplasm, robust genotyping, controlled crossing schemes, and dedicated, long-term research and selection activities.

We propose UMCA as an institutional home well-suited for this effort. The UMCA research farm [the Horticulture and Agroforestry Research Center (HARC)] maintains one of the largest repositories of chestnut cultivars in the United States. It is situated in the Missouri River Hills on very deep, welldrained Menfro silt loam soil, providing exceptional growing conditions for chestnuts. The UMCA research farm offers an excellent growing site and a secure and stable location to preserve genetic resources and display demonstration orchards. To support a robust, long-term breeding program, UMCA does have limitations: (i) finite land resources for growing and maintaining thousands of breeding progeny; (ii) periods of limited financial resources for long-term maintenance of the collections; and (iii) growing conditions that are different from those in many of the diverse growing regions of affiliated growers.

Consequently, since 2008, UMCA researchers and partner growers have widely disseminated half-sib offspring (pollinated by a highly diverse parentage) from the UMCA germplasm repository to growers throughout much of the eastern half of the United States. Approximately 7,000 offspring representing over 20 half-sib families of C. mollissima or complex hybrids cultivars are now of bearing age and are detailed by Miller (2016) and Revord et al. (2021). These plantings provide researchers and growers with robust, genetically diverse breeding populations from which growers are already identifying locally well-adapted, elite trees that serve their production needs and as candidate parents for future breeding efforts. As we enter the next cycle of genetic improvement, we envision much better coordination of growers' efforts with institutional support to create a systematic but decentralized breeding program that serves the needs of various growers in various environments.

Chestnut as a food crop is in a unique position. Due to problems with clonal propagation, most growers in the eastern United States rely on seedling populations for commercial production. Thus, the industry needs a large number of genetically superior seedlings and this creates a built-in mechanism for large-scale genetic improvement, where desired traits are recombined into superior seedlings populations. Highly dedicated and connected growers often keep detailed records on seedling origin and the year-to-year performance of trees. The combination of engaged growers, dedicated researchers, and extant genetic resources offers a highly unique opportunity to develop a participatory chestnut breeding network coordinated through the UMCA.

\section{CHESTNUT - AN EMERGING CROP FOR THE EASTERN UNITED STATES}

The chestnut (Castanea), a member of the beech family (Fagaceae), has provided value to humans through timber products, ecosystem services, livestock feed, and edible nuts. Chestnuts have been used as a dietary staple for millennia (Anagnostakis, 2012). The genus Castanea, containing at least nine species, can be found on more than 2 million hectares in 25 countries (Beccaro et al., 2019). Chestnuts grow over a broad climatic range from subtropical to severe continental climates wherever rainfall and temperatures support deciduous forest. All chestnut species require well-drained acidic soils. Chestnuts are monoecious and obligate out-crossers. Pollen is spread primarily via wind with assistance from insects. All species are highly heterozygous, and within-species genetic variation is high. All chestnut species freely hybridize and form fertile offspring. Consequently, the genetic base for chestnut breeding is vast.

The Chinese (C. mollissima), European (C. sativa), and Japanese $(C$. crenata) species are most commonly grown for their edible nuts. Interspecific hybrids involving these species and other species, especially the American chestnut [C. dentata (Marshall) Borkh], are grown throughout the eastern United States. The most prevalent species by far is the Chinese chestnut owing to its superior nut qualities, climatic adaptation, and resistance to chestnut blight and phytophthora root rot. Today, several eastern states are each annually producing tens of thousands of pounds of chestnuts that meet the high-grade standards for commercial markets (USDA, 2018) and sell out within 2 months of harvest. A large demand continues to exceed the supply, even as mature orchards and plantings expand. In 2018 , Iowa growers took $18,000 \mathrm{~kg}$ of high-grade chestnuts to market through the Prairie Grove Growers Association. Production capacity from 59 Missouri farmers ranges upwards from $4,500 \mathrm{~kg}$. In Ohio, the Route 9 Cooperative growers have steadily increased production to $45,000 \mathrm{~kg}$ with five farms of bearing age. Similar trends are observed in half a dozen other states, soon bringing the number of bearing farms from 330 to over 600. Further, growth is ongoing as the UMCA distributed open-pollinated seed from its repository to over 90 growers in the Fall of 2020.

\section{BREEDING AND SELECTION EFFORTS}

Chestnut's economic success depends on consistent yields and high nut quality, both complex traits with multiple 
components. In general, Chinese chestnuts have desirable nut characteristics, including a round shape, desirable size (10 g or higher), easy peeling, and superior flavor and texture. Nut quality defects include small or flat nuts, bitter or astringent taste, low keeping quality, mealy texture, and blossom end rot caused by Colletotrichum spp. Defective cropping traits include nut drop within the bur, excessive crop load resulting in small nut size, light crop load, and year-to-year yield variability. The breeding goal for chestnut is to identify and combine desirable attributes into an elite group of superior parents with good combining ability while maintaining or expanding a broad genetic base to accommodate future genetic gain and respond to future problems and needs. Furthermore, adaptation to the changing climate is a major challenge, phenotypic plasticity for yield and nut quality under environmental extremes (excess moisture, drought, heat stress) can be addressed by evaluation in diverse environments. Thus, there is a need to systematically identify and utilize exceptional individuals within the expansive gene pool of on-farm germplasm.

Cultivar trials and germplasm repositories have not been prominent in the United States but have been done on a modest scale by private individuals and public institutions. Grafted cultivars can be maintained in modest quantities to support curation and trialing, but issues with delayed graft failure limit cultivation of grafted trees in commercial orchards. The Connecticut Agricultural Experiment Station, the University of Missouri, and Michigan State University have ongoing germplasm curation and evaluation efforts. The USDA recently removed its orchard in Byron, GA; however, scions and seeds were collected, grown, and preserved by private enthusiasts and UMCA.

Today, chestnuts (Chinese or Chinese hybrid seedlings) are grown over a wide geographic and climatic range in the United States. After decades of evaluation, selection, and sharing of plant materials, growers have reached a threshold of genetic improvement such that commercially viable seedling orchards can be reliably established simply by planting offspring from elite selected parents (i.e., exceptional on-farm selections that performed well in subsequent replicated testing, many which were subsequently named and added to The Connecticut Experimental Station cultivar database; Anagnostakis, 2019). Collectively, growers see the substantial progress made; they see the substantial genetic variation in their plantings; they realize the potential for substantial improvement yet to be made. Growers recognize that if they continue to cooperate, and if they enlist the expertise and resources of a university, genetic improvement can achieve a rate and efficiency not otherwise attainable. In other words, individual interests are best served by a collaborative approach. Further, the economic viability of chestnut production increases in proportion to genetic improvement. While the growers' orchard trees provide financial support for the grower, those same trees can serve as in situ repositories, evaluation trials, and a source of elite parents for the next cycle of improvement, creating great value for the industry.

\section{PARTICIPATORY PLANT BREEDING}

The efficacy of participatory plant breeding efforts is welldocumented for many domesticated crops throughout the world over the last 30 years. Participatory plant breeding is currently employed to develop major crops (wheat, maize, oilseeds) adapted to local or low-input environments (Vincourt and Pierre, 2018; Bocci et al., 2020; Van Frank et al., 2020). Additionally, participatory plant breeding has contributed to the improvement of historically underutilized crops, such as quinoa (Murphy et al., 2016). In participatory plant breeding, growers are directly involved in the breeding program's decision-making, particularly in the selection of early breeding generations (Morris and Bellon, 2004; Vincourt and Pierre, 2018). The strengths and weaknesses of growers and plant breeders tend to be complementary. Growers are deeply aware of the unique challenges of their land and available market opportunities, offering practical expertise that could be translated into selection criteria. Growers also possess resources that can extend the footprint of a breeding program (Weltzien and Christinck, 2017). Cooperation with growers expands program capacity, broadens impact, and accelerates adoption compared to traditional, stand-alone, institutional breeding programs (Sperling et al., 2001; Ceccarelli and Grando, 2007; Hoffmann et al., 2007; Dawson et al., 2008). There is an incentive for programs to opt for a participatory approach when many grower preferences and target environments characterize their grower stakeholder base (Ceccarelli and Grando, 2007).

\section{Grower Engagement, Priority Setting}

Of particular importance is farmers' in-depth knowledge of their crops, encompassing performance in regional or local conditions, cultural practices, trends in emerging new pests and diseases, markets, and consumer preferences (e.g., nut size and flavor). Examples from grain crops illustrate growers' nuanced understanding of component traits, like inflorescence patterns of high-yielding cultivars (Thapa et al., 2009). Selection criteria can differ between growers and breeders and among growers, and for good reasons - with different production, marketing, and use conditions across regions. Thapa et al. (2009) studied how grower selection criteria could help breeders select locally adapted wheat. They demonstrated frequent synergies between breeders' quantitative and growers' qualitative evaluations (although there were differences), validating farmers' ability to choose superior individuals with qualitative approaches on-farm. Critical differences in assessments between breeders and growers often reflect breeders' prioritization of agronomic performance. On the other hand, growers have an intrinsic multi-trait approach that considers local conditions and preferences. If criteria differences are well-described, both classes can effectively be integrated into selection procedures in the early generations of a breeding program (Vom Brocke et al., 2010; Burman et al., 2018).

Grower involvement in conducting evaluations and making selections ensures that activities accurately reflect their preferred criteria and that sufficient genetic diversity is maintained within pedigrees for their traits of interest (Ceccarelli, 1996; Dawson 
et al., 2008; Rauf et al., 2010). Decentralized grower evaluations create the ongoing benefit of grower feedback to refine selection criteria, breeding targets (Ceccarelli and Grando, 2007), and breeding parent selection per respective target environments. Although decentralized selection and participatory plant breeding are different concepts, they are often employed together in practice (Ceccarelli et al., 2001).

\section{Decentralized On-Farm Selection}

Variation in grower environments is complex and multidimensional, especially as climate change accelerates. Fluctuations in climate make breeding new cultivars that perform over a large environmental gradient exceedingly difficult (Döring et al., 2011). Decentralized selection is typically employed when grower environments are characterized by heterogeneity in stressors, which is exacerbated by the changing climate (Ceccarelli and Grando, 2020). Since complex selection pressures of different environments are challenging to impose at a single location, evaluation directly within the different environments can be effective and efficient (Atlin et al., 2001; Dawson et al., 2008), which is even applicable for climate change-related traits (Ceccarelli et al., 2013). Decentralization is also most effective when utilizing genetically diverse, early generation material before heavy selection pressure reduces allelic diversity (Dawson et al., 2008). Thus, a decentralized breeding program leads to greater maintenance of allelic diversity than a centralized approach.

Beyond gains from major adaptations, regional yield and yield stability benefits can be expected from planting locally adapted plant materials, referred to as 'the home field advantage' (Ewing et al., 2019). Promising genotypes developed in conventional breeding programs are often defeated by unpredicted susceptibility to a particular stress within 10 years of release (Vincourt and Pierre, 2018). Promoting grower resilience and sovereignty by providing the grower agency in protecting and increasing genetic resources is a powerful platform that breeder/ population geneticists can leverage to preserve, maintain, and maximize genetic resources. Since chestnut trees are long-lived perennials, trees in any given location will occasionally experience some set of rare weather extremes during their decades-long lifespans. Evaluation and selection of individuals over a severalyear span may miss the response to one or more particular severe stress event(s). By evaluating the same families over an array of locations that experience different weather, families at one place or another will be exposed to weather extremes, thus exposing genetic vulnerabilities or tolerances. So, decentralized selection allows selection for local adaptation and also more reliably exposes potential genetic vulnerabilities.

In the case of chestnut in the eastern United States, an essential characteristic of using seedling orchards for commercial production is that orchards are initially planted at high density $(2-4 \mathrm{x}$ the final density). The trees are then thinned as they get larger and begin to compete with each other. The initial high density provides early income for the grower and the opportunity to cull the poorer performing individuals, increasing the average performance of the remaining trees and the planting overall. Consequently, chestnut growers are accustomed to observing trait variation and selecting superior individuals, and the standard practices for developing a seedling production orchard meshes well with on-farm selection for the breeding program.

Furthermore, since many trees are to be removed from a production orchard, it is practical to incorporate families from which limited superior individuals are expected. In practice, a production orchard can have two types of families: 1) those with a high mean performance value but low variance and 2) those with a low mean value of performance but high variance (e.g., interspecific hybrids). Populations from the first group represent potential incremental improvements from their parents. In contrast, the second population group would require greater culling but contain unique recombinants representing a high rate of genetic gain.

\section{A PARTICIPATORY NETWORK FOR CHESTNUT BREEDING IN THE UNITED STATES}

The UMCA and chestnut growers throughout the eastern United States are partnering to form a participatory breeding program - the Chestnut Improvement Network. The UMCA is committed to providing an organizational structure and leadership in carrying out coordinated genetic improvement. Chestnut growers offer structural capacity by cultivating seedling production orchards that double as decentralized Chestnut Improvement Network breeding populations. Figure 1 depicts the complementary roles, resources, and activities between growers and the UMCA and; organized through the Chestnut Improvement Network.

\section{Germplasm}

The UMCA initiated an extensive germplasm collection and evaluation effort (Mori et al., 2017) in the late 1990s with the help of key partners. The primary collection was assembled into a field repository between 1996 and 2005 and represented 65 cultivars conserved for long-term evaluation (Hunt et al., 2004). Fifty-four cultivars are still maintained and are described in Revord et al. (2021): 39 C. mollissima, six C. sativa $\times$ C. crenata, and nine other various or complex hybrids. Eleven cultivars, mostly hybrids (e.g., C. sativa $\times$ C. crenata 'Colossal'), have been lost due to blight or poor growth. Based on geographic origin and descriptions from their donors, 12 of the collection's most promising cultivars were selected for a replicated performance trial (established in 1999; Hunt et al., 2004, 2012). A foremost objective was to identify individuals well-adapted to the mid-Missouri climate with consistent production and nut qualities suitable for commercial markets (e.g., large, round, sweet, easy peeling, and low defects). These evaluations at UMCA and concurrent evaluations by growers have been used to inform seedling orchard establishment across the eastern chestnut region in the United States.

The distribution of seedlings from the UMCA repository and other sources has populated the chestnut growing region 


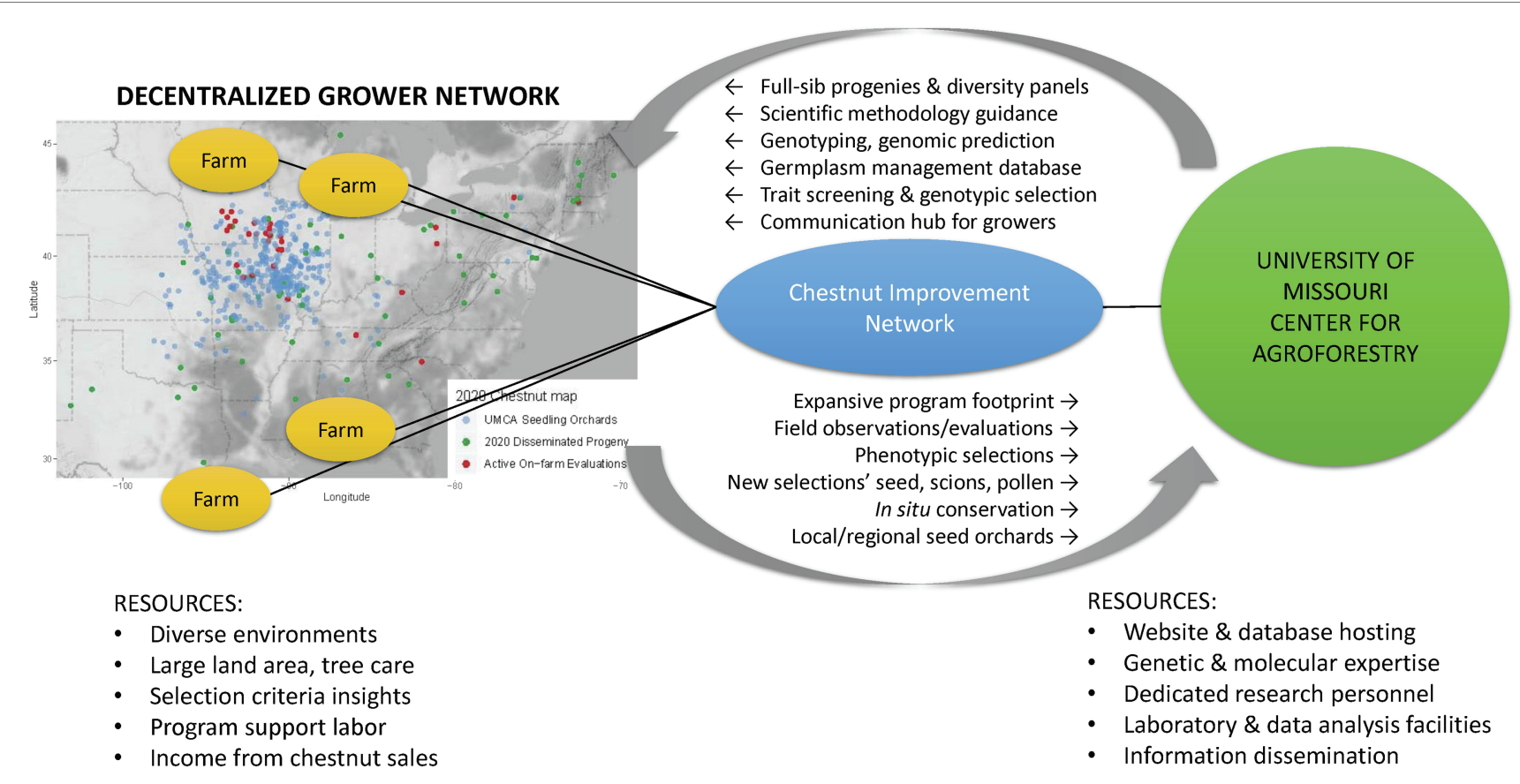

FIGURE 1 | A diagram showing the complimentary roles, resources, and activities amongst the Chestnut Improvement Network. The map depicts the distribution of a grower subset that is cultivating seedling orchards from the University of Missouri Center for Agroforestry repository: bearing orchards (blue), 2020 seed distributed (green), and current on-farm evaluations (red).

with genetically diverse half-sib progeny from C. mollissima or complex hybrid cultivars. Families and individuals have shown and will continue to show differential responses to abiotic and biotic stressors throughout the chestnut growing region. Winter cold hardiness and short growing seasons are major selection pressures in northern environments (USDA hardiness zones five and lower). Further, newly expanding shoots in the spring are vulnerable to temperatures below $-2.2^{\circ} \mathrm{C}$, so spring frost is a critical concern throughout the chestnut region. Thus, there is also a need to select for frost avoidance (i.e., late leafing). Pests and diseases, such as chestnut gall wasp, chestnut weevil, phytophthora root rot, chestnut blight, oak wilt, blossom end rot, and others, are all maladies for which genetic resistance exists and, in some cases, may be the only form of control available.

Together, growers and the UMCA are systematically evaluating on-farm progeny as potential parents of genetically diverse fulland half-sib populations to be tested under various local conditions. Selection pressure for local adaptation to various growing conditions is only effective when adequate genetic variation exists and selective conditions (e.g., severe cold) occur. Seedling orchards will also diverge for various economic traits, which are under assessment in tandem with adaptive characteristics. Consequently, the multi-trait selection requirements of on-farm evaluations mean they must be based on large populations, which become effectively larger when coordinated across many farms. Collective grower knowledge, insights, and ideas are also critically important so that evaluations can be continually refined to identify individual trees that best serve growers' needs (Hunt et al., 2012).
At present, over 600 selected seedling trees are under evaluation on-farm for seven agronomic traits, five leaf morphologies, 16 nut and kernel quality traits, and the incidence of seven pests and diseases (Table 1, Figure 2). The trees under evaluation represent over 40 growers and 20 states. UMCA specialists are carrying out assessments of agronomic traits and pest/disease incidence on-site (from 2020 to 2023). Leaf and nut samples are collected and brought to UMCA for later evaluation. Growers outside of our geographic range of in-person evaluations can participate by shipping 50-nut samples to the UMCA for evaluation. Field phenotyping guides are available to distant participants as an optional component of data collection. Multivariate analysis will explore the genetic diversity that exists for these traits amongst the on-farm selections. Additionally, genotyping with a set of around 60 EST-SSR markers (Romero-Severson, unpublished) will confirm maternal parentage, identify paternal parentage, ascertain the ancestry of complex Castanea hybrids, and provide permanent genetic fingerprints for the seedling trees. This marker set was derived from the C. molissima 'Vanuxem' reference genome (Staton et al., 2020) and subsequently crossreferenced in the to be published $C$. dentata reference genome. Growers collect dormant twigs in the winter or juvenile leaf tissue following bud break for DNA extraction and genotyping, regardless of their geographic location. The core collections assembled from this research will be conserved via combined in situ management in addition to the ex situ repository at HARC. Subsequently, the materials will be incorporated into improvement schemes as a part of the decentralized breeding program with chestnut growers. 
TABLE 1 | Descriptive standards for phenotypic data collected during on-farm and field trial observations.

\begin{tabular}{|c|c|c|c|}
\hline Trait & Definition & Methodology & Reference \\
\hline \multicolumn{4}{|l|}{ Production } \\
\hline Bearing & The tree is producing fruit & $\begin{array}{l}\text { The presence or absence of fruit on the } \\
\text { tree }\end{array}$ & \\
\hline Vigor & $\begin{array}{l}\text { Overall size and shoot extension and } \\
\text { growth relative to nearby trees of the same } \\
\text { age }\end{array}$ & Visual rating: low, medium, or high & UPOV, 2017 \\
\hline Crop load & $\begin{array}{l}\text { Overall estimate of the crop load based on } \\
\text { the number of burs in the canopy } \\
\text { compared to other trees of similar age in } \\
\text { the orchard }\end{array}$ & $\begin{array}{l}\text { Visual rating: none, low, medium, high, } \\
\text { or extra high }\end{array}$ & Greg Miller, personal communication \\
\hline \multicolumn{4}{|l|}{ Tree morphology } \\
\hline Trunk diameter & $\begin{array}{l}\text { Measurement of the size and growth of the } \\
\text { tree at a given location }\end{array}$ & $\begin{array}{l}\text { Calculated from the circumference of } \\
\text { the tree }(\mathrm{cm}) \text { taken at } 30 \mathrm{~cm} \text { above the } \\
\text { root collar using a field tape }\end{array}$ & \\
\hline Branch growth habit & The structure of the canopy of the tree & $\begin{array}{l}\text { Visual rating: upright, semi-upright, } \\
\text { spreading }\end{array}$ & UPOV, 2017 \\
\hline Degrees of looseness & $\begin{array}{l}\text { The structure of the canopy in terms of light } \\
\text { penetration }\end{array}$ & Visual rating: dense, intermediate, loose & Greg Miller, personal communication \\
\hline \multicolumn{4}{|l|}{ Leaf morphology } \\
\hline Leaf length & $\begin{array}{l}\text { Measurement from proximal end to basal } \\
\text { end of the leaf }\end{array}$ & $\mathrm{mm}$ & UPOV, 2017 \\
\hline Leaf width & $\begin{array}{l}\text { Measurement from side to side at its widest } \\
\text { point }\end{array}$ & $\mathrm{mm}$ & UPOV, 2017 \\
\hline Petiole length & $\begin{array}{l}\text { Measurement of the petiole attached to the } \\
\text { leaf }\end{array}$ & $\mathrm{mm}$ & UPOV, 2017 \\
\hline Leaf length/petiole ratio & Ratio of the leaf length and the petiole & & UPOV, 2017 \\
\hline Leaf length/width ratio & Ratio of the leaf length and the petiole & & UPOV, 2017 \\
\hline Leaf shape & Characterization of the leaf shape & Lanceolate, narrow elliptic, broad elliptic & UPOV, 2017 \\
\hline Leaf margin shape & Characterization of the margin of the leaf & Needle shape, acute, flare shape & UPOV, 2017 \\
\hline Underside pubescence and hair & Morphology of the underside of the leaf & $\begin{array}{l}\text { Presence or absence of pubescence or } \\
\text { hair on the underside of the leaf }\end{array}$ & \\
\hline \multicolumn{4}{|l|}{ Nut and kernel morphology } \\
\hline Nut width & Measurement from side to side of the nut & $\mathrm{mm}$ & Poljak et al., 2012, 2016 \\
\hline Nut length & Measurement from top to bottom of the nut & $\mathrm{mm}$ & Poljak et al., 2012, 2016 \\
\hline Nut depth & Measurement from front to back of the nut & $\mathrm{mm}$ & Poljak et al., 2012, 2016 \\
\hline Number of flat sides & Count of number of flat sides of the nut & 0 (round), 1, 2 & Poljak et al., 2012, 2016 \\
\hline Nut mass & Measurement of the mass of the nut & $g$ & Poljak et al., 2012, 2016 \\
\hline Ease of peeling & Measurement of the peeling process & $\begin{array}{l}0 \text { (peels in one or two chunks), } 1 \text { (peels } \\
\text { in } 3 \text { or } 4 \text { chunk), } 2 \text { (difficult to peel and } \\
\text { shell breaks into small pieces) }\end{array}$ & \\
\hline Pellicle adhesion & Measurement of the pellicle on the kernel & $\begin{array}{l}0 \text { ( } 75 \text { to } 100 \% \text { pellicle removal), } 1 \text { (50 to } \\
75 \% \text { pellicle removal), } 2 \text { (0 to } 50 \% \\
\text { pellicle removal) }\end{array}$ & UPOV, 2017 \\
\hline Kernel invagination & Pellicle growing into the kernel & Presence or absence & UPOV, 2017 \\
\hline Nut embryony & Number of embryos forming the kernel & Mono- or poly- embryonic & UPOV, 2017 \\
\hline Kernel color & The color of the kernel under the pellicle & Yellow, light yellow, white & UPOV, 2017 \\
\hline \multicolumn{4}{|l|}{ Pests and disease } \\
\hline $\begin{array}{l}\text { Chestnut blight or other stem } \\
\text { cankers }\end{array}$ & $\begin{array}{l}\text { The formation of trunk/stem cankers on } \\
\text { growing trees using a 5-level rating scale }\end{array}$ & $\begin{array}{l}0=\text { no cankers, } 1 \text { = few superficial } \\
\text { cankers with no effect on tree growth, } \\
2=\text { more obvious swollen cankers with } \\
\text { deleterious effects on growth, but no } \\
\text { stem death, } 3=\text { obvious swollen } \\
\text { cankers with some branch death and/or } \\
\text { severe stunting of branch growth, } \\
\text { perhaps epicormic branching, } 4=\text { large } \\
\text { branches dead with } 30-70 \% \text { of the } \\
\text { crown dead, usually basal sprouting, } \\
5=\text { whole tree dead from a canker with } \\
\text { stump sprouting }\end{array}$ & Hebard, 2005 \\
\hline Phytophthora & $\begin{array}{l}\text { Tree death without sprouting, phytophthora } \\
\text { confirmed with diagnostic test or presence } \\
\text { of dark "flaming" under the bark at base of } \\
\text { the tree }\end{array}$ & Presence or absence & Santos et al., 2015 \\
\hline
\end{tabular}


TABLE 1 | Continued

\begin{tabular}{|c|c|c|c|}
\hline Trait & Definition & Methodology & Reference \\
\hline Oak wilt & $\begin{array}{l}\text { Tree death or decline with oak wilt } \\
\text { symptoms including leaf shedding }\end{array}$ & Presence or absence & Greg Miller, personal communication \\
\hline Oak shot hole leaf miner & $\begin{array}{l}\text { A very small fly that lays its eggs by } \\
\text { piercing developing leaves with her } \\
\text { ovipositor. The holes where eggs were laid } \\
\text { become larger as the leaves expand. }\end{array}$ & $0,1,2$, or 3 scale based on severity & Boggs, 2021 \\
\hline Asian gall wasp & Formation of galls on the shoot tips & $0,1,2$, or 3 scale based on severity & Hunt et al., 2012 \\
\hline Chestnut weevil & $\begin{array}{l}\text { Evidence on the outside or inside of the nut } \\
\text { from chestnut weevil larvae }\end{array}$ & Presence or absence & Hunt et al., 2012 \\
\hline Chestnut blossom end rot & $\begin{array}{l}\text { Black spoilage on the proximal end of the } \\
\text { nut. Also referred to as chestnut } \\
\text { anthracnose }\end{array}$ & Presence or absence & Miller, 2017 \\
\hline \multicolumn{4}{|l|}{ Tree phenology } \\
\hline Green leaf tips visible & First green leaf tips just visible & Julian date & Larue et al., 2021 \\
\hline First leaves unfold & Leaves first beginning to unfold & Julian date & Larue et al., 2021 \\
\hline Beginning shoot growth & Beginning of shoot elongation & Julian date & Larue et al., 2021 \\
\hline First appearance of male catkins & $\begin{array}{l}\text { First appearance of developing male } \\
\text { catkins }\end{array}$ & Julian date & Larue et al., 2021 \\
\hline $\begin{array}{l}\text { First appearance of female } \\
\text { inflorescence on bi-sexual catkins }\end{array}$ & $\begin{array}{l}\text { First appearance of female inflorescence on } \\
\text { bi-sexual catkins }\end{array}$ & Julian date & Larue et al., 2021 \\
\hline First male flowers open & Male catkins first opening & Julian date & Larue et al., 2021 \\
\hline $10-20 \%$ of male flowers open & $10-20 \%$ of male catkins open & Julian date & Larue et al., 2021 \\
\hline Full male flowering & At least $50 \%$ of male catkins open & Julian date & Larue et al., 2021 \\
\hline Catkins fading & At least $50 \%$ of male catkins turning brown & Julian date & Larue et al., 2021 \\
\hline Stigma visible & $\begin{array}{l}\text { Stigma of the central female inflorescence } \\
\text { visible }\end{array}$ & Julian date & Larue et al., 2021 \\
\hline Full receptivity & $\begin{array}{l}\text { Full receptivity of female inflorescence: } \\
\text { stigma elongated and open }\end{array}$ & Julian date & Larue et al., 2021 \\
\hline Female flowers fading & $\begin{array}{l}\text { At least } 50 \% \text { of female flowers have brown } \\
\text { stigmas }\end{array}$ & Julian date & Larue et al., 2021 \\
\hline
\end{tabular}

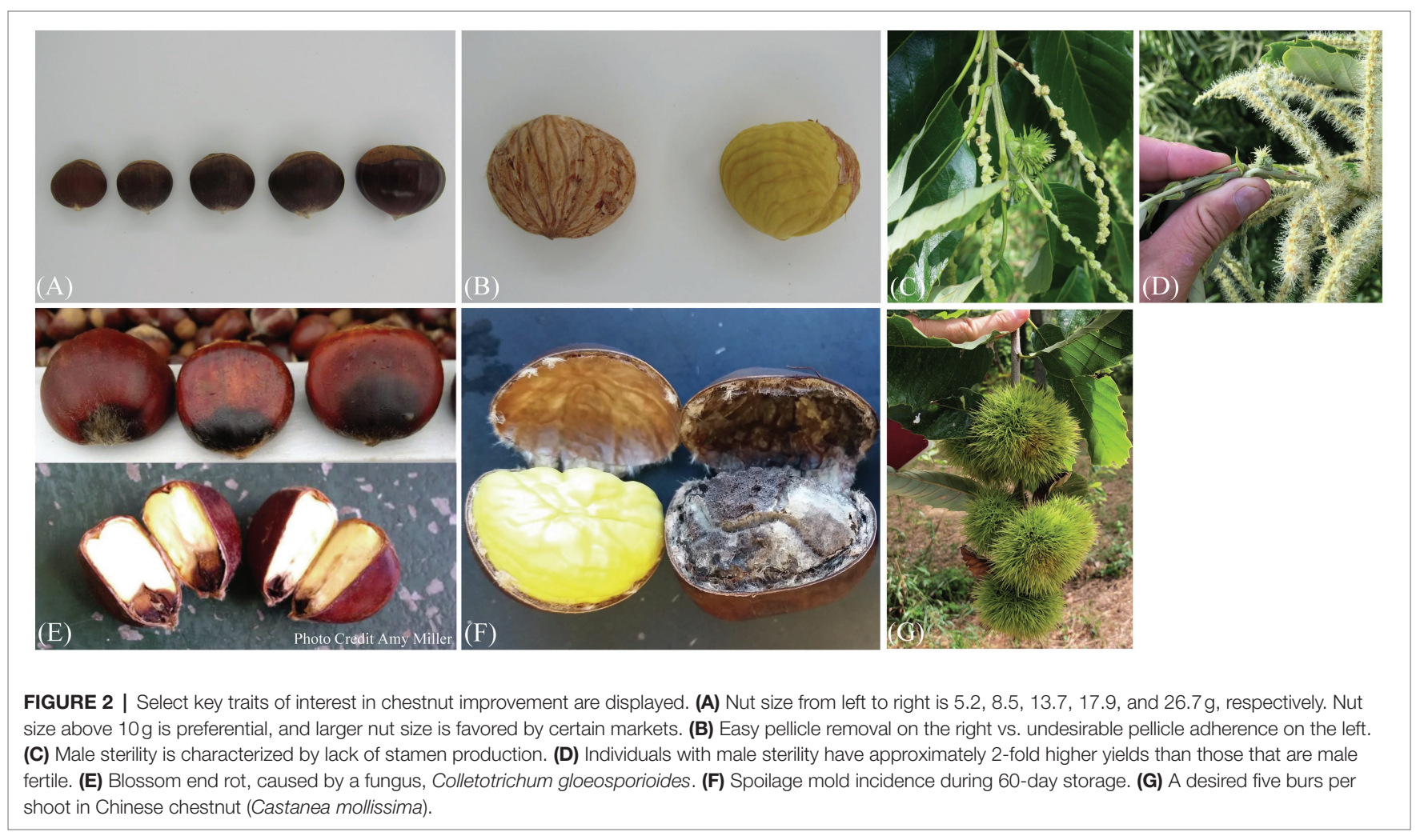




\section{Formalizing the Chestnut Improvement Network}

The value of on-farm selections as a genetic resource comes from the whole of assembled collections rather than individual trees and locations. Thus, to maximize the benefit to participating growers, the selections from network farms must be made available to the grower network, with the caveat that local or regional adaptations may limit wide-range applicability. At this stage of chestnut industry development, growers are not in competition with each other. Instead, they are striving to attain a critical industrial mass that will foster industry-wide economies of scale.

While on-farm locations provide the structural capacity to cultivate, identify, and conserve new and improved genetic variants, the institutional home provides the knowledge base, perspective, and facilities to design and coordinate an improvement scheme. Looking forward, we will deploy three population types to growers: (1) grafted seed orchard populations, (2) diverse panels of seedling families that are balanced in size, and (3) full-siblings of new pedigree schemes derived from controlled crosses. Population types one and two are deployed, using the UMCA 'Peach' $\times$ 'Qing' $\times$ 'Kohr' seed orchard and the cultivar repository, respectively. Full-sibling offspring from UMCA pedigree schemes will be disseminated starting 2021 , with a volume of five to ten thousand individuals annually. At present, these three populations are systematically utilizing the diversity present in the HARC repository and represent a major advance since past ad hoc open-pollinated seed dispersal. On-farm selections will be incorporated into these schemes over the next several years.

Evaluation of new seedling progeny descending from these population types will be conducted by both UMCA specialists and regional network technicians. A germplasm management database, E-Brida 6.0 (E-Brida, 2021), will facilitate quality control measures for accurate breeding stock record-keeping from deployment through data collection. QR code labels will ensure accurate nursery handling, field layout, and plot map documentation during on-farm establishment. These labels will be replaced as seedlings enter bearing years and data collection begins. E-Brida's field application aids data collection quality control and ease by using tablets. Scanning the $\mathrm{QR}$ labels routes the user to the pedigree ID of the respective seedling. Data Properties (i.e., phenotypes) are predefined within the system and "toggled" on/off based on the assessment activities of the day/season to form digital data sheets with consistency across the network. Time-stamped images can also be uploaded in tandem with phenotypes to assist with validating data quality. Data on the application can be synced and archived on the cloud database once the tablet is connected to Wi-Fi.

Data collection priorities are hierarchical and vary by population type, family, and seedling age. Generally, evaluation and selection at the progeny-level will occur in seed orchard families or at the individual level in diverse family panels and full-sibling pedigrees. Evaluation of progeny in seed orchard families will prioritize valuable commercial traits, such as yield, interannual yield variability, nut quality, and defects. Mean progeny performance and variance will be assessed by replication ( $n \geq 30$ trees, $r=4-5)$ in complete randomized blocked orchards. Evaluation of individual trees with diverse family panels and full-sibling pedigrees incorporates wider criteria but on a family-specific basis respective to the goals of that pedigree/cross (e.g., narrow harvesting window, nuts that drop from burs, lower quality defects). Evaluation criteria will be expanded (e.g., to yield, nut attributes) on "retained" individuals that represent improvements for the requisite traits. Progeny tests will guide the commercial scaling of select seed orchards per environment, and individual selections will be incorporated into breeding schemes and replicated testing in ideal environments.

Replicated performance trials can subsequently serve as seed orchards and genetic repositories, as has happened, and will continue at the UMCA farm. Institutional involvement in the breeding program will allow more sophisticated phenotyping and genotyping, leading to more strategic crossing schemes, faster genetic gains, and integrity of germplasm tracking. Many US chestnut farmers have strong skills and experience in making selections from large populations of individuals. Growers are often capable and enthusiastic about carrying out field evaluations with proper training. UMCA specialists will continue to facilitate on-farm evaluations on a scale that matches the volume of next-generation seedling orchards planted.

The UMCA is committed to providing this institutional capacity, both in infrastructure and leadership, to the decentralized genetic improvement of chestnuts. We will work with growers to develop the organizational structure, recordkeeping, and information dissemination to serve growers' interests and our university mission. This approach can also be adapted to other long-lived perennial crops, as this is an effective way to conduct broad-scale genetic improvement programs for such crops.

\section{DATA AVAILABILITY STATEMENT}

The original contributions presented in the study are included in the article/Supplementary Material, further inquiries can be directed to the corresponding author.

\section{AUTHOR CONTRIBUTIONS}

RR, GM, NM, and JW drafted the manuscript. RR and GM edited the manuscript. GM, SL, and JR-S contributed significantly to conceiving, writing, and editing the manuscript. GM has been a pivotal leader in conceiving and organizing participatory chestnut improvement in the eastern United States for decades. GM and MG have curated cultivars and disseminated their seedlings to growers. RR, GM, JR-S, and $M G$ initiated on-farm evaluations and the Chestnut Improvement Network in partnership with growers. All authors contributed to the article and approved the submitted version. 


\section{FUNDING}

This work is supported by the USDA Agricultural Marketing Service, Agreement No. AM190200XXXXG010, and the University of Missouri Center for Agroforestry and the USDA/ARS Dale Bumpers Small Farm Research Center, Agreement numbers 58-6020-6-001 and 58-6020-0-007 from the USDA Agricultural Research Service.

\section{REFERENCES}

Anagnostakis, S. L. (2012). Chestnut breeding in the United States for disease and insect resistance. Plant Dis. 96, 1392-1403. doi: 10.1094/PDIS-04-12-0350$\mathrm{FE}$

Anagnostakis, S.L. (2019). The Connecticut agricultural experiment station. Available at: https://portal.ct.gov/-/media/CAES/DOCUMENTS/Biographies/ Anagnostakis/CULTIVARS-OF-CHESTNUT-9-2020.pdf (Accessed August 1, 2021).

Atlin, G. N., Cooper, M., and Bjørnstad, Å. (2001). A comparison of formal and participatory breeding approaches using selection theory. Euphytica 122, 463-475. doi: 10.1023/A:1017557307800

Beccaro, G., Alma, A., Bounous, G., and Gomes-Laranjo, J. (2019). The Chestnut Handbook: Crop \& Forest Management. Boca Raton: CRC Press.

Bocci, R., Bussi, B., Petitti, M., Franciolini, R., Altavilla, V., Galluzzi, G., et al. (2020). Yield, yield stability and farmers' preferences of evolutionary populations of bread wheat: A dynamic solution to climate change. Eur. J. Agron. 121, 126-156. doi: 10.1016/j.eja.2020.126156

Boggs, J. (2021) "Breaking News: Oak Shothole Leafminer on Chestnut." Ohio State University BYGL. Available at: https://bygl.osu.edu/node/1797 (Accessed: August 23, 2021).

Burman, D., Maji, B., Singh, S., Mandal, S., Sarangi, S. K., Bandyopadhyay, B. K., et al. (2018). Participatory evaluation guides the development and selection of farmers' preferred rice varieties for salt-and flood-affected coastal deltas of south and Southeast Asia. Field Crop Res. 220, 67-77. doi: 10.1016/j. fcr.2017.03.009

Ceccarelli, S. (1996). Adaptation to low/high input cultivation. Euphytica 92, 203-214. doi: 10.1007/BF00022846

Ceccarelli, S., Galie, A., and Grando, S. (2013). "Participatory breeding for climate change-related traits" in Genomics and Breeding for Climate-Resilient Crops. (Verlag Berlin Heidelberg: Springer), 331-376.

Ceccarelli, S., and Grando, S. (2007). Decentralized-participatory plant breeding: an example of demand driven research. Euphytica 155, 349-360. doi: 10.1007/ s10681-006-9336-8

Ceccarelli, S., and Grando, S. (2020). Evolutionary plant breeding as a response to the complexity of climate change. Iscience 23:101815. doi: $10.1016 / \mathrm{j}$. isci.2020.101815

Ceccarelli, S., Grando, S., Amri, A., Asaad, F. A., Benbelkacem, A., Harrabi, M., et al. (2001). "Decentralized and participatory plant breeding for marginal environments" in Broadening the Genetic Base of Crop Production. eds. H. D. Cooper, C. Spillane and T. Hodgkin ( CAB International), 115-135.

Dawson, J. C., Murphy, K. M., and Jones, S. S. (2008). Decentralized selection and participatory approaches in plant breeding for low-input systems. Euphytica 160, 143-154. doi: 10.1007/s10681-007-9533-0

Döring, T. F., Knapp, S., Kovacs, G., Murphy, K., and Wolfe, M. S. (2011). Evolutionary plant breeding in cereals-into a new era. Sustainability 3, 1944-1971. doi: 10.3390/su3101944

E-Brida 2021. EBrida 6.0. Available at: https://www.e-brida.com/ (Accessed: August 24, 2021).

Ewing, P. M., Runck, B. C., Kono, T. Y., and Kantar, M. B. (2019). The home field advantage of modern plant breeding. PLoS One 14:e0227079. doi: 10.1371/journal.pone.0227079

Hebard, F. (2005). The backcross breeding program of the American chestnut foundation. J. Am. Chestnut Found. 19, 55-78.

Hoffmann, V., Probst, K., and Christinck, A. (2007). Farmers and researchers: how can collaborative advantages be created in participatory research and technology development? Agric. Hum. Values 24, 355-368. doi: 10.1007/ s10460-007-9072-2

\section{ACKNOWLEDGMENTS}

The authors would like to thank the many members of the eastern United States chestnut community - growers, enthusiasts, and researchers - that have progressed chestnut improvement for nut production. Special thanks to Amy Miller for providing images used in Figure 2.

Hunt, K., Gold, M.A., Reid, W., and Warmund, M. R (2012). Growing Chinese Chestnuts in Missouri. University of Missouri Center for Agroforestry, Agroforestry in Action. AF1007. Available at: https://extension.missouri.edu/ media/wysiwyg/Extensiondata/Pub/pdf/agguides/agroforestry/af1007.pdf (Accessed: June 1, 2021).

Hunt, K. L., Gold, M. A., and Warmund, M. R. (2004). Chinese chestnut cultivar performance in Missouri. Acta Hortic. 693, 145-148. doi: 10.17660/ ActaHortic.2005.693.15

Larue, C., Barreneche, T., and Petit, R. J. (2021). Efficient monitoring of phenology in chestnuts. Sci. Hortic. 281:109958. doi: 10.1016/j.scienta.2021.109958

Miller, G. (2016) Cooperative chestnut breeding in the USA. Chestnut Growers of America. Available at: http://www.chestnutgrowers.org/GregMillerCooperativeBreeding.pdf (Accessed: November 16, 2020).

Miller, G. (2017) "Blossom End Rot of Chestnut: a small problem becomes a big problem.” Chestnut Growers of America: The Chestnut Grower 18, 1-4. Available at: http://www.chestnutgrowers.org/TheChestnutGrower-January2017web.pdf (Accessed: August 23, 2021).

Mori, G. O., Gold, M., and Jose, S. (2017). "Specialty crops in temperate agroforestry systems: sustainable management, marketing and promotion for the Midwest region of the USA" in Integrating Landscapes: Agroforestry for Biodiversity Conservation and Food Sovereignty. ed. F. Montagnini (Cham: Springer), 331-366.

Morris, M. L., and Bellon, M. R. (2004). Participatory plant breeding research: opportunities and challenges for the international crop improvement system. Euphytica 136, 21-35. doi: 10.1023/B:EUPH.0000019509.37769.b1

Murphy, K. M., Bazile, D., Kellogg, J., and Rahmanian, M. (2016). Development of a worldwide consortium on evolutionary participatory breeding in quinoa. Front. Plant Sci. 7:608. doi: 10.3389/fpls.2016.00608

Poljak, I., Idžojtić, M., Zebec, M., and Perković, N. (2012). The variability of European sweet chestnut (Castanea sativa Mill.) in the region of Northwest Croatia according to morphology of fruits. Sumar. List 136, 479-489.

Poljak, I., Vahčić, N., Gačić, M., and Idžojtić, M. (2016). Morphology and chemical composition of fruits of the traditional Croatian chestnut variety 'Lovran Marron'. Food Technol. Biotechnol. 54, 189-199. doi: 10.17113/ ftb.54.02.16.4319

Rauf, S., da Silva, J. T., Khan, A. A., and Naveed, A. (2010). Consequences of plant breeding on genetic diversity. Int. J. Plant Breed. 4, 1-21.

Revord, R. S., Nave, J. M., Miller, G., Meier, N., Webber, J. B., Gold, M. A., et al. (2021). Descriptions of chestnut cultivars for nut production in the eastern and midwestern U.S. HortSci. 56, 1315-1324. doi: 10.21273/HORTSCI16090-21

Santos, C., Machado, H., Correia, I., Gomes, F., Gomes-Laranjo, J., and Costa, R. (2015). Phenotyping Castanea hybrids for Phytophthora cinnamomi resistance. Plant Pathol. 64, 901-910. doi: 10.1111/ppa.12313

Sperling, L., Ashby, J. A., Smith, M. E., Weltzien, E., and McGuire, S. (2001). A framework for analyzing participatory plant breeding approaches and results. Euphytica 122, 439-450. doi: 10.1023/A:1017505323730

Staton, M., Addo-Quaye, C., Cannon, N., Yu, J., Zhebentyayeva, T., Huff, M., et al. (2020). A reference genome assembly and adaptive trait analysis of Castanea mollissima 'Vanuxem,' a source of resistance to chestnut blight in restoration breeding. Tree Genet. Genomes 16:57. doi: 10.1007/s11295-020-01454-y

Thapa, D. B., Sharma, R. C., Mudwari, A., Ortiz-Ferrara, G., Sharma, S., Basnet, R. K., et al. (2009). Identifying superior wheat cultivars in participatory research on resource poor farms. Field Crop Res. 112, 124-130. doi: 10.1016/j. fcr.2009.01.011

UPOV (2017) Chestnuts (Castanea mollissima Blume; Castanea creneta Siebold \& Zucc.; Castanea sativa Mill.); guidelines for the conduct of test for distinctness homogeneity and stability. UPOV, Geneva, Switzerland. 
USDA (2018). Noncitrus fruits and Nuts 2017 Summary. Available at: https:// www.nass.usda.gov/Publications/Todays_Reports/reports/ncit0618.pdf (Accessed: December 01, 2020).

Van Frank, G., Rivière, P., Pin, S., Baltassat, R., Berthellot, J.-F., Caizergues, F., et al. (2020). Genetic diversity and stability of performance of wheat population varieties developed by participatory breeding. Sustainability 12:384. doi: 10.3390/su12010384

Vincourt, P., and Pierre, C. (2018). Alternative breeding processes: at which extent participatory breeding should modify the concept of ideotypes in plant breeding? OCL 25, D606-D606. doi: 10.1051/ocl/2018061

Vom Brocke, K., Trouche, G., Weltzien, E., Barro-Kondombo, C. P., Gozé, E., and Chantereau, J. (2010). Participatory variety development for sorghum in Burkina Faso: Farmers' selection and farmers' criteria. Field Crop Res. 119, 183-194. doi: 10.1016/j.fcr.2010.07.005

Weltzien, E., and Christinck, A. (2017). "Participatory breeding: developing improved and relevant crop varieties with farmers" in Agricultural Systems. eds. S. Snapp and B. Pound (Elsevier San Diego, CA: Academic Press), 259-301.
Conflict of Interest: The authors declare that the research was conducted in the absence of any commercial or financial relationships that could be construed as a potential conflict of interest.

Publisher's Note: All claims expressed in this article are solely those of the authors and do not necessarily represent those of their affiliated organizations, or those of the publisher, the editors and the reviewers. Any product that may be evaluated in this article, or claim that may be made by its manufacturer, is not guaranteed or endorsed by the publisher.

Copyright (๑) 2022 Revord, Miller, Meier, Webber, Romero-Severson, Gold and Lovell. This is an open-access article distributed under the terms of the Creative Commons Attribution License (CC BY). The use, distribution or reproduction in other forums is permitted, provided the original author(s) and the copyright owner(s) are credited and that the original publication in this journal is cited, in accordance with accepted academic practice. No use, distribution or reproduction is permitted which does not comply with these terms. 